\title{
2 nye medlemmer i NFUD styret
}

I forbindelse med årets symposium i Sandefjord var det tid for valg av leder og styremedlemmer i NFUD. Roald Flesland Havre ble gjenvalgt som leder. Eva Tegnander fortsetter som styremedlem og tar på seg sekretæroppgaven. Rune Hansen tar ansvar for NFUD sitt nettsted, www. nfud.no. I styret forblir Beatrice Rüger, Thomas Reiher som kasserer, og Peter Montzka med ansvar for Flaggermusen. Vivi Bakkeheim er permittert fra sine oppgaver i styret, og revmatologisk overlege ved Ålesund sjukehus Hallvard Fremstad stiller som vikar for henne på styrets forespørsel.

Etter mangeårig innsats i styret takket Claudia Heien og Svein-Erik Måsøy for seg på årets NFUD symposium i Sandefjord. Claudia holdt som sekretær orden på styrets aktiviteter og stod ikke minst for fjorårets symposium i Stavanger. SveinErik hadde bl.a. ansvar for NFUD nettsiden.

Vi ønsker Nils Petter Oveland og Kari Utne velkommen som nye styremedlemmer. Begge to har formidabel erfaring med ultralyd og styret gleder seg til nye impulser og konstruktivt samarbeid.

Nils Petter Oveland studerte medisin ved Universitet i Bergen. Turnuslegeperioden tilbrakte han ved Asker og Bærum Sykehus og i Hitra kommune. Etter verneplikt som lege har han fra 2004 jobbet som an- estesilege ved Stavanger Universitetssykehus. Fra 2008 har han vært ph.d. kandidat ved Universitet i Bergen, finansiert av Stif-

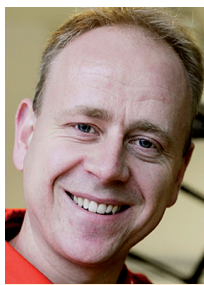

Nils Petter Oveland telsen Norsk Luftambulanse. Doktorgradsarbeidet handler om bruk av ultralyd for å oppdage pneumothorax hos traumepasienter, og avhandlingen skal forsvares høsten 2013. Nils Petter har regelmessig stått bak arrangement av praktiske ultralydkurs, helt fra student- opp til spesialistnivå. Han fikk prisen for beste frie foredrag på fjorårets NFUD symposium i Stavanger.

Kari Utne er utdannet sykepleier ved Røde Kors sykepleierskole i Tønsberg. Etter 2 år ved Regionsykehuset i Tromsø fulgte Jordmorhøyskole i Bergen og turnustjeneste ved Lillehammer fylkessykehus.

Årene etter arbeidet hun i Oslo som jordmor ved Aker sykehus, Ullevål universitetssykehus, Volvat medisinske senter og

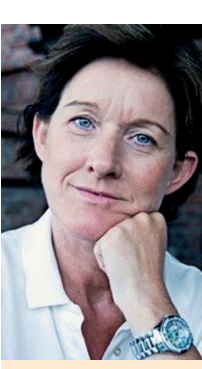

Kari Utne Frogner helsestasjon. Kari Utne har mangeårig erfaring med ultralyd etter utdanning og kurs ved Nasjonalt senter for fostermedisin. Hun har vært ansatt siden 1990 ved fødeavdelingen og poliklinikken ved Stavanger universitetssykehus. Ved siden av har hun i 15 år drevet privatpraksis som ultralydjordmor. Hun har deltatt på kurs, kongresser og aktivt på NFUD sine symposier med frie foredrag.

For styret

Peter Montzka 